\title{
Doing an EKG on America's Heartland: A Review Essay
}

\author{
Joseph Frazier WaLl
}

Heartland: Comparative Histories of the Midwestern States, edited by James H. Madison. Bloomington: Indiana University Press, 1988. vii, 308 pp. Maps, notes, bibliographical essays, index. \$29.95 cloth.

IS THERE A MIDDLE WEST? Yes, Virginia, there is a Middle West, as you and all of the other states in the Union well know. Indeed, this region, after years of being treated at best with neglect and at worst with scorn, has now been rediscovered, much to the surprise of its inhabitants. A national news magazine announced recently that the Midwest is "the latest hot place in which to live." But what it is - or even where it is - is not so easy to determine. When newspaper editors and reporters were asked what states should be included in the Middle West, the results of the poll clearly revealed what a vague, amorphous section it is even in the minds of those who use the term most frequently: Iowa was the only state that appeared on every journalist's list of midwestern states.

All right. So we can all agree that Iowa is a midwestern state. But what other states can lay claim to this regional appellation? Even the inhabitants of this vast area have no clear concept of the extent of the territory to which they belong. To lowans and Kansans it seems absurd to include Ohio within their region. That state is far more closely allied economically and socially with Pennsylvania than it is with South Dakota and Nebraska. The prairie states generally would be quite content to use the central time zone as the east-west boundaries of their region. This would admit Indiana for at least six months of the year but would unfor-

THE ANNALS OF IOWA 50 (Spring 1990). (C) The State Historical Society of Iowa, 1990. 
tunately cut the Dakotas, Nebraska, and Kansas in two. Most Ohioans and Michiganders, on the other hand, would not extend their region beyond lowa and Minnesota, for once one crosses the 98th meridian, one enters what early nineteenth-century mapmakers labeled the Great American Desert. To eastern midwesterners, the four plains states serve only as a dull and seemingly endless prelude to the dramatic and majestic symphony that is the Rocky Mountain area-something one must endure in order to reach Aspen, Vail, Jackson Hole, and Sun Valley.

Defining boundaries has always been a problem for this recognized but ill-defined section of the country. It lacks the unity that geography has given to New England or that political history has given to the eleven southern states of the former Confederacy. Some would say that it is wrong to incorporate into a single section this vast, diverse territory lying somewhere west of Pennsylvania and east of Colorado. They would insist instead on subdividing it into the Great Lakes states, the prairie states, and the plains states.

Clearly, there is no precise definition of the Middle West on which its inhabitants and the rest of the nation can agree. The editor of Heartland, Professor James H. Madison of Indiana University, decided, wisely in my opinion, not to concern himself with this seemingly irresolvable problem. He arbitrarily and decisively defined the Middle West as consisting of twelve statesOhio, Michigan, Wisconsin, Indiana, Illinois, Iowa, Minnesota, Missouri, North Dakota, South Dakota, Nebraska, and Kansas - and asked a historian in each of those states to write a short interpretative essay on that state. "This collection of essays is intended to help all know more about the people who live in the American heartland, to know its residents as citizens of a singular state and a singular region," Madison tells his readers in an introductory chapter. "To this end, the twelve essays in the volume have three major characteris:ics: they are historical; they are analytical; and they are comparative" $(1,3)$. With descending order of success, the twelve essays do demonstrate these three characteristics. They are most successful in their expository, historical narratives, only slightly less successful in their analyses of the historical events the authors selected as important for their states, and least successful, though often entertaining, in the comparison of their individual state with the other eleven states of the region. 
Madison asserts that these essays will serve as "powerful antidotes to assumptions of homogeneity in America and in the Midwest. . . . The heartland is a heterogeneous place. Not only does its landscape take different forms, so too does its political and social life" (5). Indeed they do, as might be expected within a territory comprising one-fourth of the total area of the coterminous continental United States. This theme of heterogeneity is also stressed by most of the authors for their individual states, claiming for each a heterogeneous population, acting within a rapidly changing culture, placed within a highly varied landscape, and finding unity only by the arbitrarily drawn boundaries that Congress had recognized in admitting each state into the Union. Only in the essays on Kansas, North Dakota, and especially lowa (perhaps, in the last instance, excessively so) is homogeneity given paramountcy over heterogeneity.

If, however, heterogeneity is quite correctly a dominant theme for most of these essays, there is, paradoxically, considerable homogeneity in both method and style of development among the twelve essays. Nearly all of the authors give primary emphasis to the political and economic history of their states. The coming of the railroad to their region is a theme that binds all of these states together. Great attention is given in most instances to the native American inhabitants in each state, understandably so for the two Dakotas, less so for Iowa. Only in the essays on Ohio and Indiana (in spite of the name given to the latter state) are the original inhabitants largely ignored. The terrain of each state is of course a major concern for each author. Only in the case of Michigan is water of greater importance than land. The twelve authors also select the same national historical phenomena to emphasize as dominant events in the history of their states: the Civil War, the depressions of the 1890s and the 1930s, Progressivism, and the impact of two world wars. Only in three of the four most western states, however, is Populism given much attention. Most of these twelve historians have been influenced most not by a fellow historian (although there is the customary acknowledgment of debt to Frederick Jackson Turner), but rather by a political scientist, Daniel Elazar. In one way or another, the authors attempt to place their individual states within Elazar's spectrum, which ranges from a job-oriented, marketplace mentality to that of an issue-oriented, moralistic, commonwealth ideal. 
All twelve authors deal competently with the economic and political histories of their state. David B. Danbom and Herbert T. Hoover, the authors of the essays on North and South Dakota, respectively, are to be especially commended for the emphasis given to the continuing colonial status of their states. Limited to no more than thirty pages, "with most of the essays not exceeding twenty-five pages, the authors have done a remarkable job of selection and condensation. Even recognizing this space limitation, however, readers may be somewhat surprised by what is omitted as well as by what has been given heavy emphasis. The La Follettes receive their proper due in John Buenker's essay on Wisconsin, but he gives more attention to Charles McCarthy, the first director of the state's Legislative Reference Bureau than to that other Wisconsin McCarthy who gave his name to a particular era in American history. Frederick Luebke devotes two paragraphs to the reforms of Nebraska's Progressive Republican governor Samuel McKelvie, but Populism merits only half a sentence, and William Jennings Bryan's name never appears. To write an essay on Nebraska, no matter how cursory the treatment must be, without mentioning the Boy Orator of the Platte is somewhat analogous to writing a short history of the American presidency with a chapter on William Howard Taft but no mention of Andrew Jackson. Perhaps most surprising is the attention Peter Harstad gives to Thomas R. Marshall, who emerges in these pages as the "genial guide to the middle period of Indiana history." Harstad is to-be commended for rescuing Marshall from political oblivion and giving to Woodrow Wilson's vicepresident a greater claim to historical fame than simply as the author of that oft-quoted statement, "What this country needs is a good five cent cigar." There may yet be hope for the current Hoosier vice-president of the United States to receive favorable attention from future historians.

The most serious omission in most of these essays is the lack of attention given to the cultural achievements of midwestern writers and artists. Notable exceptions to this criticism are the comments by Cullom Davis on architecture in Illinois, by Dorothy Schwieder on lowa artist Grant Wood and novelist Curtis Harnack, by Annette Atkins on Minnesota's popular culture as reflected in "The Mary Tyler Moore Show" and Garrison Keillor's "Prairie Home Companion," and by Herbert Hoover on art and 
literature in South Dakota. But the reader looks in vain for any recognition of Missouri artists George Caleb Bingham and Thomas Hart Benton, or of Frank Lloyd Wright's Taliesin school of architecture in Spring Green, Wisconsin.

In the comparative histories of the twelve states the reader will find the most lively and provocative comments - but also the most errors of fact and judgment. Comparisons are always far more entertaining than they are odious, but they do inevitably lead to sweeping generalizations that are at best only half-truths and at worst outright falsehoods. There are few midwesterners outside of Missouri who would agree with the author of that state's history and with the editor of this work that Missouri, because of its diversity, has "a less precise sense of state identity" than most states. Iowans generally find that of all their neighbors the Show Me state is exceeded in its state pride only by Kansas and Minnesota. In contrast, Iowa is surpassed in self-deprecation only by North Dakota, as Schwieder's and Danbom's essays clearly reveal. Danbom's article, in its modesty and candor, comes as a refreshing change from the strong note of boosterism sounded in many of the other essays. Even though many of the other historians might well have done so, none gives such a flat, unequivocally critical judgment of his or her state as does Danbom, who begins his essay by stating, "North Dakota never realized its future" (107).

Madison tells us that "each historian thought in comparative contexts while writing the essay, and each circulated early drafts of the essay among all participants" (3). If that is so, then a few egregious errors of comparison must have crept into the manuscripts in later drafts, for it is difficult to believe that any Minnesotan would allow Kansas to lay claim to being "the largest midwestern state in area" (252). The Kansas historian, Leo Oliva, on the other hand, could feel justifiably wronged by Peter Harstad's historical error in denying to Kansas statehood at the beginning of the Civil War (171), particularly when the state of Kansas claims the honor of having "furnished more troops per capita" than any other state, including Indiana (259).

One of the most interesting and original essays in the collection is Luebke's essay on Nebraska. Denying the importance of a state psyche, which Dorothy Creigh had used as the theme of her 
history of Nebraska for the Bicentennial States and the Nation Series, Luebke offers as a substitute approach "the interplay of culture with environment over time," by which he means a state's "distinctiveness is revealed through appropriate comparisons in time and space" (228). Luebke successfully develops and sustains this theme throughout most of the essay, but eventually he, along with all of the other authors, becomes caught up in a concern for his state's psyche. He concludes his essay by stating that Nebraskans are "individualistic, self-reliant and conservative, but they have been willing to use radical means to achieve their conservative goals" (244). Something similar might just as well have been said, and indeed is said, about Iowa, North Dakota, Ohio, Michigan, and Kansas. One cannot, and probably should not, attempt to avoid generalizations about a state psyche, whether it is or is not unique to that state, for boundaries, no matter how arbitrarily drawn, do eventually create within the contained territory a unifying culture and mind-set, as anyone who may attempt to erase the artificial boundaries separating North from South Korea, or East from West Germany will surely discover. Luebke is quite right in saying that time and space create a distinctiveness, but that in turn creates a prevailing psyche that most of the inhabitants of that territory will accept as valid.

Iowa may claim to be, as Schwieder says, the true middle land, but each of Schwieder's eleven coauthors is equally insistent that her or his state is the real Middle West, and that, in turn, means, in Madison's words, "the most American part of America." A favorite word throughout this collection is "microcosm." Ohio, Illinois, Missouri, and Kansas all claim to be America in microcosm as well as "the epitome of midwestern distinctiveness." Even Danbom sheds his modesty on this point, boldly subtitling his essay on North Dakota "The Most Midwestern State," and justifying that claim with the original argument that since "North Dakota has changed less than most of the region, it remains more midwestern" (121). It is perhaps as impossible as it is stupid to try to pick out the one state that has the best claim to the title. Yet Cullom Davis's excellent essay convinced me that Illinois is indeed, as Davis claims, the true "cross section" not only of the Middle West but also of the nation, with all of its promise and all of its problems. If you would know the Heartland, do as Davis sug- 
gests. Travel down that main artery from Chicago across that neatly squared "Illinoleum" of tilled fields to Cairo, Illinois. In so doing, you will also come to know America.

If you cannot do that - or even if you do-then read this book. This single volume does for the Middle West essentially what James Morton Smith hoped to do for the entire nation with his fifty-volume Bicentennial States and the Nation Series. Every American, not just midwesterners, should applaud this effort by James $\mathrm{H}$. Madison and his twelve authors. The Middle West may not be definitively encompassed in this volume, but Heartland makes clear that the region does exist and, like a patchwork quilt, does find a unity in spite of its diversity. 
Copyright of Annals of Iowa is the property of State of Iowa, by \& through the State Historical Society of Iowa and its content may not be copied or emailed to multiple sites or posted to a listserv without the copyright holder's express written permission. However, users may print, download, or email articles for individual use. 